Article

\title{
Creaturely Communal Ontology in Practice: John Zizioulas in Dialogue with Ritual Theory
}

\author{
John W. Compton IV \\ Center for Biomedical Ethics and Society, Vanderbilt University Medical Center, Nashville, TN 37232, USA; \\ john.w.compton.1@vumc.org
}

Received: 1 August 2019; Accepted: 25 August 2019; Published: 28 August 2019

\begin{abstract}
This article is born out of a deep concern for our current ecological crisis and serves as a beginning foundational work for how the Christian tradition can address global climate change. Our current way of being gives precedence to the autonomous individual, whose freedom is characterized by disregard for other creatures. John Zizioulas' communal ontology demonstrates that as the world was created out of God's loving will, it is comprised of relationship. Living into individuation and division is a refusal of this communion with other creatures and God, but the Eucharist serves as the ritual that brings Christians into communion through the remembrance of Christ. Ian McFarland's work on the theology of creation provides the helpful nuance that creaturely movement in communion must include the full diversity of creatures. I then turn to Bruce Morrill's work to demonstrate that the Eucharistic practice must have bearing beyond the walls of the church. It leads practitioners to live into eschatological hope and kenotic service to the world. John Seligman's ritual theory demonstrates that ritual practice can accomplish these goals because it creates a subjunctive 'as-if' world in the face of the world that is perceived as chaotic. Through the continuous practice of the ritual, participants are then formed to live into this subjunctive 'as-if' world without ritual precedence. In this way, the Eucharistic practice can prepare practitioners to live into the kenotic service to a world broken by individuation that has led to global climate change and creaturely destruction.
\end{abstract}

Keywords: John Zizioulas; communal ontology; ritual theory; creation; climate change

\section{Introduction}

One of the central characteristics of the late modern world is the primacy given to the autonomous individual, free to choose one's direction without societal strictures or consequences. This emphasis on the individual has been one of the contributing factors to the current ecological crisis manifest in global climate change: As humans see the individual as the only point of reference, any sense of relation to the rest of creation is ultimately forgotten. John D. Zizioulas' Being as Communion: Studies in Personhood of the Church demonstrates that from a Christian perspective true existence is only possible in relation with other persons and God. Though Zizioulas' communal ontology does have cosmological and practical dimensions, there is still the danger that such community does not involve the full richness of God's creation, such that these theories could never leave the walls of the church or the world of ideas. In this paper, I bring Zizioulas into conversation with Ian McFarland's notion of creaturely movement to sharpen this cosmological element in his communal, sacramental ontology. I then turn to Bruce Morrill's work to clearly understand the anamnestic character of the sacrament of the Eucharist. Finally, I bring this theological trajectory into practical focus through the ritual theoretical work of Adam Seligman and colleagues in Ritual and Its Consequences: An Essay on the Limits of Sincerity. This paper, then, serves as a foundation for exploring the ways in which Christian ritual practice can confront ecologically disastrous practices that are characteristic of late modern life. 


\section{Zizioulas: A Communal Ontology of Church and Sacraments}

Zizioulas begins developing his notion of a communal ontology by turning to early arguments for Trinitarian Christian faith. In these attempts, the early Church Fathers faced the challenge of giving ontological content to each person of the Trinity while maintaining monotheistic biblical faith. The debates surrounding Trinitarian thought are well-known, but Zizioulas argues that what is most significant here is the philosophical revolution that took place when early Christians identified divine hypostasis with divine person (Zizioulas 2002). These arguments resulted in the philosophical notion that the person is constitutive of being and, therefore, that entities trace being back to the person, rather than being itself. These arguments could only be possible within Christian understanding of the world (Zizioulas 2002). Specifically, Zizioulas highlights that the world is not necessary in Christian cosmology. He writes that there is a "radical difference in ontology, to trace the world back to an ontology outside the world, that is, to God," which means that the world is a product of freedom, rather than necessity (Zizioulas 2002). In a Christian understanding of God, identifying the being of the world with the being of God means that, at its center, the world is fundamentally comprised by relationship. With the being of the world contingent on relationship to God, one must first understand God's relation to God's self. Therefore, Zizioulas emphasizes that for the Greek Fathers the unity of God consists in the person of the Father: "If God exists, He exists because the Father exists, that is, He who out of love freely begets the Son and brings forth the Spirit" (Zizioulas 2002). In this way, Christianity offers a unique understanding of ontology that situates the being of the world as a product of absolute freedom on behalf of the being of God that is the person of the Father.

A key element for understanding the weight of these arguments is Athanasius' response to Arianism. The first part of Athanasius' argument was his distinction between substance and will, which highlighted that the being of the Son is of the same substance as the Father and distinct from the being of the world (Zizioulas 2002). Zizioulas writes, "To say that the Son belongs to God's substance implies that substance possesses almost by definition a relational character" (Zizioulas 2002). In this way, then, relationality becomes an ontological category. Then, Zizioulas demonstrates that the Cappadocians identified the term hypostasis with prosopon. This last term is relational in nature, thereby making being in relation necessary for being at all (Zizioulas 2002). Consequently, the being of the world, even as it is a product of the will of God, is derived from the being of God. This distinction between substance and will, along with the Cappadocian development in relational ontology, leads Zizoulas to argue for a Christian understanding of the world as created by God out of freedom, rather than out of necessity.

Zizioulas maintains that this notion is not simply an academic idea abstracted from human experience. Because the being of the world is identified with the being of God, who creates in absolute freedom, there is a sense in which the world also shares in this freedom. Zizioulas, however, demonstrates that because creation is distinct from God, creatures experience the necessity of existence as a challenge to this freedom (Zizioulas 2002). He argues that for the human, there is a drive to transcend this necessity such that the human reality is a product of freedom, and yet, without a theological understanding of this freedom, this drive will inevitably end in nihilism (Zizioulas 2002). ${ }^{1}$ Here, Zizioulas turns to theology to demonstrate that humans need an ontology rooted in that "which does not suffer from createdness" (Zizioulas 2002). Christ is the historical reality by which this sort ontology is possible for humanity. Because Christ was born of a virgin and is fully human and fully divine, he subsists in the same way that God the Father subsists: "Christology consequently is the proclamation to man that his nature can be 'assumed' and hypostasized in a manner free from ontological necessity of his biological hypostasis, which ... leads to individualism and death"

1 See also Groppe (2005), who shows that, for Zizioulas, the most tragic aspect of human existence is that humans are unable to determine the beginning of their existence. Along these lines, Zizioulas, 42, points to Dostoyevsky, who proclaims through the character Kirilov in The Possessed that the only way for humans to obtain total freedom is through suicide. 
(Zizioulas 2002). Zizioulas then turns to ritual to begin parsing out how humans are able to transcend biological necessity and enter into authentic personhood.

Through the sacramental ritual of baptism, humans come into a new relationship with the world as an ecclesial being. As such, their relation to the world is no longer limited to biological necessity. Zizioulas argues that since a human's baptism in Christ is the ritual death and resurrection of that individual, she or he dies to individuality and is resurrected into community: "The resurrectional aspect of baptism is therefore nothing other than incorporation into the community" (Zizioulas 2002). It is the relationships among these different people and with God that comprise humans as genuine persons, bringing them into an eschatological or sacramental hypostasis in the church. Zizioulas argues that in the ecclesial celebration of the Eucharist, humans are able to transcend the created necessity limiting whom one can love: "The Eucharist is the only historical context of human existence where the terms 'father,' 'brother,' etc., lose their biological exclusiveness and reveal ... relationships of free and universal love" (Zizioulas 2002). Encapsulated within the Eucharist is an eschatological dialectic in which humans feel a tension between the ecclesial and biological hypostasis. We feel a hope and desire to be fully that ecclesial being received from God while simultaneously living within the necessities of created biology. The body is not denied in the Eucharist and its eschatological hope. Instead, the body is ritually transformed, such that biological needs no longer determine the person's being: “The body, for its part as the hypostatic expression of the human person, is liberated from individualism and egocentricity and becomes a supreme expression of community-the Body of Christ, the body of the Church, the body of the eucharist" (Zizioulas 2002). The person, then, draws its being from the future, hoping for full realization of the resurrection-reality accomplished by Christ through participation in the ritual remembrance of the mystery of redemption in the Eucharist. This remembrance includes the living and the dead, such that the dead are not merely commemorated as passed away but, rather, there is an "assurance that the person has the final word over nature, in the same way that God the Creator as person and not nature had the very first word" (Zizioulas 2002).

The Eucharist is essential for Zizioulas' communal ontology because this ritualization is the place in which the truth of Christ is revealed to humanity through the very material of creation. In the Eucharist, the divisions among individuals are transcended, such that existence and communion are one-a truth coming from another world (Zizioulas 2002). The Eucharistic ritual accomplishes this reality through the embodied act of offering bread and wine to God for recapitulation. This patristic idea originates from Irenaeus and understands Christ as renewing all of creation through his incarnation. Through obedience to Christ, humanity undergoes the ongoing transformation until it is fully realized in the resurrection of the body.

Zizioulas then uses this idea to argue that within the Eucharist humans act as priests by connecting creation to God and, in so doing, make communion possible for nature, as well as for humanity (Zizioulas 2002). He argues that in being the priests of creation, humans recognize an ontological link between humanity and nature:

The Eucharist consists in taking elements from the natural world, the bread and the wine which represent the created material world, and bringing them into the hands of the human being, the hands of Christ who is the man par excellence and the priest of creation, in order to refer them to God. (Zizioulas 2011, pp. 138-39)

Of essential importance in this statement is Zizioulas' identification of bread and wine with the material world, because these elements are the products of human labor. Before the world is ritually offered back to God, to whom the world belongs, it is transformed and developed through human hands.

Zizioulas' emphasis on communion is essential because it is the basis of truth and being. ${ }^{2} \mathrm{He}$ argues that creaturely truth is dependent truth requiring participation in God. What gives creation

2 For a full historical theological survey of this idea, see (Zizioulas 2002, pp. 67-101). 
its meaning is its movement from and toward its fulfillment in Christ, which is the logos of creation (Zizioulas 2002). As such, creation is inseparable from God's will, based in love rather than necessity, and the incarnation will be fully realized: "[Christ] represents the ultimate, unceasing will of the ecstatic love of God, who intends to lead created being into communion with His own life, to know Him and itself within this communion-event" (Zizioulas 2002). Practitioners experience communion as truth through the practiced freedom in the Eucharist, in which creatures are free from individualization and division and enter into communion. The Eucharist is a foretaste of this eschatological hope. Therefore, in the ritualization of the Eucharist, humans embody and live into the eschatological reality of authentic communal ontology by ritually bringing the world together and offering it to God in the Eucharistic communion.

Living into this authentic personhood and communion is distinct from the reality brought about by Original Sin. Zizioulas understands Original Sin as humans' refusal to live in communion with God, and instead understanding themselves as the ultimate point of reference for creation. He writes that from an ontological perspective "the fall consists in the refusal to make being dependent on communion, in a rupture between truth and communion" (Zizioulas 2002). Therefore, instead of being in communion with God, the true person who created the world, creation is referred to the finite, created human being limited by biological necessity. Through participating in the Eucharist, however, humans are ascetically trained to live beyond this necessity and refer creation back to God, with humans then serving as a link connecting God and creation (Zizioulas 2011). In other words, humans live into the truth of Christ that is practiced in the Eucharist and is conditioned by the epicletic (Spirit-invoked) and anamnetic (memory-invoking) character of that ritual (Zizioulas 2002). Zizioulas argues that the Spirit brings the eschata into history, transforming history from mere recollection of past events to a remembrance of the future. Bruce Morrill's work in Anamnesis as Dangerous Memory: Political and Liturgical Theology in Dialogue can provide some very helpful nuance to this eschatological understanding of the Eucharist by delving into the meaning of anamnesis and how it is practiced.

\section{Eucharist: Eschatological Remembrance toward the Communion of All Creation}

Morrill turns to the biblical scholarship of Nils Alstrup Dahl to demonstrate that in early Christian communities, anamnesis was "a recollection of the gnosis given to all those who have believed in the gospel, received baptism, and been incorporated into the church" (Morrill 2000). Specifically, Morrill shows that in the New Testament when Paul commands believers to remember their baptism, he is calling them to the remembrance of a knowledge known in an embodied way through the ritual of baptism. However, because the believers live in a fallen world, this knowledge remains a mystery, such that the life of the community must be continuously interrupted by the message of the Gospel (Morrill 2000). The Eucharist serves as this interruptive practice. Drawing upon the influential Orthodox theologian Alexander Schmemann, Morrill demonstrates that it is a break "from perceived reality of this fallen world [to] experience the vision of what God will yet bring about in the redeemed creation" (Morrill 2000). Morrill goes on to state that though this break is an interruption of time, it does not uphold a dichotomy between the profane and the sacred. Instead, the eschatological knowledge of a redeemed world is symbolically conveyed in the ritual. Nonetheless critical of the extent to which Schmemann believes eschatological vision to be so fully realized in the sacramental ritual, Morrill offers a helpful nuance by turning to Geoffrey Wainwright's demonstration (from early Christian literature) of how the Eucharist involves the expectation of both Christ's presence in the ritual and his final advent (Morrill 2000). Consequently, Morrill is able to highlight the eschatological dialectic within the Eucharist between the dangerous memory of Christ's suffering and the consolation of redemption it inaugurates (Morrill 2000). Morrill illustrates that the Eucharistic practice does more than simply console or train Christians to live as persons. In fact, the ritually engaged memory of the entirety of God's action in Christ draws Eucharistic participants into a dangerous memory, empowering them for lives of kenotic service to the world. Morrill's nuance demonstrates that this communal ontology 
cannot stay within the bounds of the ritual. Instead, it must push participants to engage more fully with the world.

This engagement with the world must, moreover, involve not just humans, but the entirety of creation. Zizioulas certainly has a cosmological sense in his understanding of the Eucharist, while Ian McFarland's notion of creaturely movement highlights the ways in which considering all of creation can substantiate a communal ontology. Like Zizioulas, McFarland argues that creation receives its being from God, with the Christian understanding of God as Triune imparting a relational understanding of God and, therefore, of creation. However, McFarland also highlights that one of the ways that creation is most distinct from God is its movement toward creaturely perfection (McFarland 2014). He shows that because God created that which is not God ex nihilo, creatures are not perfect, but that "it was possible ... for creatures to attain a creaturely analogue to divine perfection over time as a gift from God" (McFarland 2014). Creatures' movement toward creaturely perfection is driven by a fundamental lack of the fullness of existence, which belongs only to the Triune God. In this movement, creatures are always dependent on God and other creatures: "These relationships shape the contours of creaturely movement, so that the process by which any creature becomes present to God is inseparable from its interactions with other creatures" (McFarland 2014). McFarland has a rich understanding of creation that includes humans, animals, microorganisms in soil, and even forces like electromagnetism and gravity (McFarland 2014). This understanding of a relational creation dependent on God and interdependent with other creatures deepens Zizioulas' communal ontology, expanding the ecclesial hypostasis from only interhuman relations to the rich diversity across creation. Such a view provides nuance to Zizioulas' understanding of the Eucharist as the place in which Christians practice the communal ontology.

Zizioulas is clear that in the Eucharist, humans act as the priests of creation by bringing the material world together and recapitulating it back to God. From this notion, Zizioulas avers that the protection of nature and the development of nature are not mutually exclusive: "The human being is the priest of creation in the sense that the material world he takes in his hands is transformed into something better than what it is naturally" (Zizioulas 2011). Zizioulas can thereby point to the Eucharist as the place in which humans symbolically gather all of creation through their labor of making bread from wheat and wine from grapes to offer it to God. McFarland's notion of creaturely movement is helpful here, showing the mutual involvement of all creatures in their movement toward communion, as theirs is a constitutive interdependence. Specifically, in preparing the bread and the wine, the human acting as the priest of creation is relating with a vast array of creatures, such as wheat, water, salt, yeast, and even bacteria on the practitioner's hands. By preparing the bread and the wine for the ritualization of the Eucharist, humans relate to one another and these creatures and, in doing so, participate in the movement toward creaturely perfection.

Zizioulas highlights the way that humans are integral for the development of creation (Zizioulas 2011), ${ }^{3}$ while McFarland advances this understanding of the ways that the Eucharist ascetically trains Christians (Zizioulas's term), bringing believers into the eschatological dialectic Morrill described. By relating the production of wheat and grapes to bread and wine, humans acting as priests of creation are confronted by the uniqueness of these creatures, such that they cannot be developed into anything other than the possibilities of their endemic potential. To attempt to do otherwise refuses communion with those creatures and refers creation back to the human instead of God. Therefore, in the practice of preparing the elements, Christians are trained through their relation with these creatures and live beyond the biological necessity of createdness by bringing all of creation into communion with God. Relating to creatures in this way, moreover, refers back to Morrill's highlighting of the eschatological tension between the dangerous memory and consolation of Christ. By developing creation and offering

3 Zizioulas argues here that humans occupy a unique place in creation, in that they are ontologically tied to it while simultaneously able to transcend it through freedom. 
it to God, humans live in kenotic service to the world and live in hope for the full realization of the redeemed creation.

It must be noted here that the sacrament of the Eucharist rests on the sacramentality of the world. This idea means that while the ritual serves both as a practice of remembrance of God's redeeming work in the world and a way for Christians to live into that work, creation is full of God's grace. Alexander Schmemann succinctly states this idea thusly:

... the world, be it in its totality as cosmos, or in its life and becoming as time and history, is an epiphany of God, a means of His [sic] revelation, a rationally acceptable case of its existence, but only truly speaks of Him and is in itself an essential means both of knowledge of God and communion with Him, and to be so is its true nature and its ultimate destiny. (Schmemann 1973, p. 120)

Within this grace-filled context of the cosmos, Christians participate in the practice of the Eucharist. Practitioners use the very material of creation to produce the bread and the wine, gather as a community, and participate in the movement toward creaturely perfection. Kevin Irwin observes that creation's sacramentality reveals that "things matter and matter is not just a thing" and that sacramentality is the language of both. Irwin also notes that "In a sacramental world all is both graced and in need of complete redemption" (Irwin 2005). As members of the community of creation, Eucharistic practice confronts us with our constitutively relational condition that is both graced and in need of redemption.

Though such a communal ontology encapsulating (recapitulating) all of creation has significant merit, the danger of it becoming a set of beliefs that are only cognitively held without embodied practice remains. Here, the ritual theory of Adam Seligman and his colleagues, distinguishing between ritual and sincerity, can provide important nuances for this communal ontology.

\section{Bringing Communal Ontology into Practical, Ritual Focus}

Seligman argues that ritual creates a world out of participants' lived reality. He and his colleagues draw primarily from Jewish and Confucian sources to show that practicing ritual brings a sense of order to a world primarily experienced as chaotic. In this way, ritual creates a shared subjunctive 'as-if' world among participants (Seligman et al. 2008). Ritual is a distinctly different way of interacting with the world than what Seligman calls sincerity, by which he means the individual's having the right ideas in place before participating in the practice. Seligman succinctly makes distinction between ritual and sincerity as follows:

In doing a ritual the whole issue of our internal states is often irrelevant. What you are is what you are in the doing, which is of course an external act. This is very different from modernist concerns with sincerity and authenticity ... Getting it right is not a matter of making outer acts conform to inner beliefs. Getting it right is doing it again and again and again-it is an act of world construction. (Seligman et al. 2008, p. 24)

In other words, ritual is the practice by which a community continuously constructs a shared 'as-if' world that gives them a sense of order in contrast to a lived experience that often feels chaotic. Sincerity, in contrast, involves an inward search for authenticity that is often removed from the work of ritual. In this way, then, ritual has a flexibility that sincerity does not. When the authentic beliefs that one holds in sincerity change, there is no subjunctive 'as-if' world to maintain order. Seligman offers the example of a family that loves each other dearly but has been disrupted by some sort of conflict. In this context, it is important for the family to act as if they love each other before they sincerely do (Seligman et al. 2008).

Giving primacy to active practice, rather than cognitive belief, opens this shared world for different individuals. In the practice of ritual, that is, through the ritual act, different individuals construct a shared world: "Sharing the act, they both point to or index the shared world that is their relationship" (Seligman et al. 2008). Difference among the individuals does not collapse into a single consciousness in the ritual act. Instead, the ritual act serves as the way in which individuals are able to enter this 
shared, subjunctive, 'as-if' world. This subjunctive world, nonetheless, exists in direct tension with and in response to the reality lived outside of the ritual. Specifically, Seligman demonstrates that "the subjunctive world created by ritual is always doomed ultimately to fail-the ordered world of flawless repetition can never fully replace the broken world of experience" (Seligman et al. 2008). Essentially, because ritual creates a shared world of order amongst participants, the ritual is not a reflection of some sort of (sincerely conceived) harmonious world. The human work of ritual is ongoing, as its participants strive to create harmony amidst reality's discordance. This tragic sense of the world is precisely why the work of ritual is important for human existence. By participating in a ritual, individuals are able to enter into a constructed world of order, which then allows them to live as if the subjunctive world of ritual is the world of reality. This phenomenon is not a result of actively thinking about the disjunction between the ritual world and lived experience. Instead, participants are living into this 'as-if' world through the act itself (Seligman et al. 2008). There is great responsibility among humans to enact ceaselessly these rituals in response to the chaotic lived experience in order to create an ordered subjunctive 'as-if' world.

In making their case for ritual's priority over sincerity, Seligman and his colleagues draw primarily from a fourth-century BCE Chinese document asserting that humans are to "build patterns of relationships out of this fractured world and thereby create an ordered way of life" (Seligman et al. 2008). The text further maintains that it is proper for humans to have a fixed purpose, attained through repeated study. Such study does not mean transcending a context, it means "refining one's responses to situations" (Seligman et al. 2008). One of the ways that humans participate in this repeated study is enacting rituals and practices from the past. Seligman explains:

These rituals, then, arose from the dispositions themselves: they were simply actions taken in response to certain situations in the past. But the later-born sages deemed some of these actions exemplary, and as such defined them as part of a ritual canon that people in general should enact. The goal of such an enactment would be to refine one's own dispositions: by reenacting exemplary actions from the past, one trains one's responses so that one can achieve propriety. (Seligman et al. 2008, pp. 33-34)

Ritual, then, becomes a set of relations that is in tension with the world of lived experience, prompting the question of how participants are to act outside of the world of ritual. Again, working from Confucian writings, Seligman demonstrates that one of the goals of ritual is to continue into this subjunctive 'as-if' world, even outside of the ritualization (Seligman et al. 2008). He writes that "if one spends one's life doing rituals properly, then one gains a sense of how the subjunctive world constructed out of these rituals could be constructed in situations without ritual precedent" (Seligman et al. 2008). This way of framing the relation between the ritual world and the world of lived experience highlights the efficacy of ritualized acts, as opposed to acts governed solely by sincerity. Specifically, through the repeated "study" by ritual, one is able to live in the midst of the chaotic world by living as if one is in the subjunctive, ordered world of ritual instead of relying on the sincere, abstracted world of ideas.

Because practicing rituals can serve as a way for participants to navigate the world of chaos outside of the ritualization, ritual also provides a different understanding of autonomy. Seligman contrasts ritual's sense of autonomy with that of sincerity's, which calls for individuals to be uninhibited by anything other than the self (the individual's inward examination to determine authenticity) (Seligman et al. 2008). In ritual, autonomy is precisely the result of a person who is able to act without "ritual precedent" (Seligman et al. 2008). Seligman turns to the Jewish rabbinic tradition, wherein the goal of becoming a rabbi "is to be achieved through a submission to ritual" such that " $\mathrm{t}]$ he inner comes to reflect the outer, and not the other way around" (Seligman et al. 2008). This means that autonomy comes about through relations with others, with traditions being comprised of the voices and practices of people from the past. In contrast, working within a sincere mode puts an intense amount of responsibility upon the individual, since it is only through that single individual's search for an authentic self that the individual determines action. Consequently, there is no shared world among 
individuals and no practices by which individuals can enter a shared world. Seligman explains, "The establishment of a stable and unquestionable $a s$ is, rather than a common $a$ if if, becomes the projected basis for the intersubjective world" (Seligman et al. 2008). Therefore, the individual self becomes the only point of reference for autonomy, as opposed to the community conditioned by the tradition of ritual.

This ritual-based understanding of autonomy is evident in the way that ritual accepts authoritative procedures within the world created it creates. Sincerity views such authority structures as mere convention and, thus, unauthentic. Ritual, in contrast, sees them as a formative force in creating a subjunctive world, providing order to the lived experience of chaos. Seligman depicts this difference by distinguishing how community love is accomplished in Confucian and Mohist arguments. The Mohist relied on the inward transformation of individuals, whereas the Confucian emphasis on ritual argued that "social peace would come through ... the constraints of ritual repetition" (Seligman et al. 2008). In the ritual, both the future and the will are circumscribed through the repetition. In regard to the future, Seligman argues that in revisiting the past through the ritual, the unlimited future possibilities are placed in a frame of already known (i.e., past) experiences. Ritual constrains through prescribed gestures and words and creates a community thereby able to embrace both the past and the future (Seligman et al. 2008). Likewise, this same repetition circumscribes the individual will by placing "the individual actor in a very particular relation to a body of practices (or even modes of speech and addresses), a way of being, which imposes obligations" (Seligman et al. 2008). This repetition makes the past present again. By way of Kierkegaard, Seligman demonstrates that a modern sense of repetition is like the ancient Greek understanding of recollection, except performed in the opposite direction. Specifically, repetition is a way of recollecting forward. He argues that repetition "stamps a shape onto the formlessness and chaos of existence" (Seligman et al. 2008). In this way, then, Seligman and his colleagues show that the practices of ritual form a community through sharing a common past, creating a subjunctive world, and orienting toward a shared future formed by the repetition of that past, all of which comes about in the very practice of the ritual, rather than the sincere search for inward authenticity among individuals.

The theoretical work of Seligman and his colleagues provides some clarity as to how Zizioulas's communal ontology, as substantiated by Morrill and McFarland, is practiced in the Eucharist. One of the key elements of Seligman's theory is the way in which ritual provides a sense of order to a world that is experienced as chaotic. Zizioulas provides a Christian theological rendering of this notion by asserting both that God created the world ex nihilo and that Original Sin comprises a (chaos-inducing) refusal of communion between the world and God. In his essay, "Proprietors or Priests of Creation," Zizioulas argues that because God created the world from nothing, it will return to nothingness unless it is brought into communion with God. That communion can only come about through the agency of humans, who occupy the unique position in creation as priests due to their ability to transcend createdness through their freedom as persons in communion (Zizioulas 2011). Because we are living in the context of Original Sin, we experience the world as chaotic precisely because humans refuse communion with other creatures and God and refer creation back to ourselves instead of God. ${ }^{4}$

The ritualization of the Eucharist is the practice by which Christians construct and provide a sense of order in the face of this chaos. The first way that this ordering takes place is in the gathering of the baptized. As Zizioulas argues, through baptism, Christians are resurrected into the community of Christ and come into an ecclesial hypostasis. Consequently, the gathering of baptized Christians for the Eucharist is an ordering of human creatures in community who can freely love one another

4 This understanding of the world is distinct from the Jewish and Confucian sources with which Seligman is dialoging, because this Christian understanding of the world sees the world as a created order that only becomes chaotic after humans refuse to maintain the communion between God and the world, which is precisely why ritual is necessary after Original Sin. Conversely, the Jewish and Confucian sources used by Seligman see the world as inherently chaotic from the beginning. See (Seligman et al. 2008). 
without the constraints of biological necessity. Then, the gathered community ritually brings together the rest of creation through developing nature, as seen in the preparation of the bread and the wine. As stated above, the human labor of making bread and wine is the relation of various creatures from wheat, water, salt, yeast, grapes, and the process of fermentation. The ritual preparation and offering in the Eucharist comprise a performance of these very different creatures relating to one another in an ordered manner, as opposed to a relation defined by chaos.

Additionally, the way in which ritual is an index by which participants enter into a subjunctive 'as-if' world that exists in tension with the world of lived experience is crucial to Seligman's theory of ritual. The Eucharist creates a world that reorients creaturely relationships, eliminating a sense of competition among different creatures. Rather, as McFarland's notion of creaturely movement demonstrates, these creatures come together into a subjunctive world created by the ritualization of the Eucharist in which they contribute to their collective movement toward perfection and communion with God. Zizioulas is, likewise, quite clear in acknowledging that the biological aspects of humans do not disappear in the practice of the Eucharist. In fact, there is a tension between what he calls the biological hypostasis and the ecclesial hypostasis. Specifically, Zizioulas argues that though humans live in this ecclesial hypostasis during the ritualization, the body is not denied in the ritual act of the Eucharist. There is always the tension and possibility that humans could direct creation toward themselves instead of God. This acknowledgment is precisely why Seligman and his colleagues carefully demonstrate that ritual is the ongoing practice and work of getting the ritual correct. It is not a matter of first establishing the correct ideas and then moving into the practice. Rather, through continuously practicing the Eucharist and creating this subjunctive 'as-if' world in which creatures relate to one another in an orderly way, Christians live into the ecclesial hypostasis, while simultaneously living in the inherent tension between the world constructed by the ritualization and the world of lived experience.

The tension between the subjunctive world and the world of lived experience is precisely the tension between the fallen world and the eschatological reality in which Christians now live in hope for its full realization in the future eschaton. Zizioulas argues that in the ritualization of the Eucharist humans live into the eschatological reality brought by the Spirit through the epiclectic and anamnestic character of the ritual (Zizioulas 2002). As discussed above, Morrill provides the necessary nuance to this notion by showing that in early Christian communities, anamnesis is the remembrance of God's past action in Christ, as well as an interruption of the eschatological reality of redeemed creation in the fallen world, calling Christians into kenotic service to the world. Seligman and his colleagues' theory of the ritual's circumscribing character of both the future and human will is also at play here. Specifically, in practicing the Eucharistic ritual, Christians remember God's past acts in history in and through Christ. In doing so, participants circumscribe the limitless possibilities of the future, which Zizioulas terms "remembering the future". Through the ritualization of the Eucharist, Christians enter into the eschatological reality and live as if the world is redeemed, with God fully realizing this redemption in the future eschaton. Also, in the same act, the traditional character of the ritual circumscribes the participants' wills through their enacting particular gestures from the Christian tradition. For example, offering the bread and wine in community, as Zizioulas demonstrates, is a practice of transcending all of humanly forged boundaries: The assembled people act as ecclesial hypostases offering creation to God as the priests of creation. In this practice, humans accept communion as necessary for being in a manner that includes all of creation, and, through gathering, developing, and recapitulating creation back to God, human persons live in service to the world.

Seligman's ritual theory demonstrates the power and flexibility of a ritual mode of being in the world because it has consequences beyond the ritual world, into the world of lived experience. This insight is important for recognizing the ways in which the subjunctive world created by the ritual can be a distinct reality only inhabited by the participants during the act of ritualization. As I noted above, Zizioulas' communal ontology is prone to this problem. Morrill's critique of Schmemann's overly realized eschatology applies here: If the eschaton is fully realized in the ritual, then there is no 
need for persons to live in service to the world outside of the act of ritualization. However, enlisting Seligman's theory shows that in continually practicing the ritual, participants are preparing themselves to act in situations and contexts beyond the ritual. Indeed, this is one of ritual's very goals. Turning to a communal ontology that takes creaturely movement and anamnesis seriously, we perceive the Eucharistic ritual shaping participants to accept communion as essential to being and to living itself. This is, moreover, a communion among all of creation. Christians thus can live within the chaotic world as if they are living in the subjunctive world created by the Eucharist—and act accordingly. The communal ontology Zizioulas conceives is, therefore, necessarily understood as practiced in an embodied way. Formed by the ritual, the participants can live into the kenotic service to the world outside their enactments of the Eucharist.

\section{Conclusions}

This project has arisen from a deep concern for living in a context defined by global climate change, and it serves as the beginning work of interrogating the ways in which Christian ritualization can be a transformative force in confronting ecologically degrading practices. In the United States, most Americans approach global climate change through sincere means. If we consider the problem at all, we do so by cognitively considering the ways we can individually address the issue. We bring reusable bags to the grocery store, purchase "green" products, or drive (alone) in a hybrid vehicle. However, this sincere approach leaves formative practices in place that substantiate divisions between humans and other creatures creating the chaotic world of rising sea levels, increased migration, spreading vector-borne illnesses, and permanent soil loss. We exist in what political theorist and bioethicist Bruce Jennings calls a consumptive social contract (Jennings 2016). ${ }^{5}$ We mindlessly consume without regard for each other or the inherent limits of our consumption's foundation, namely, the closed ecological system that makes life and creaturely flourishing possible. In other words, our current way of being rests on limiting non-human creaturely movement for the sake of our own individualized consumption. We live in the truth of being, rather than the truth of communion, and we do so at total creaturely peril.

The Eucharistic practice, as I have described it here, interrupts the foundations of this consumptive social contract, creating the subjunctive 'as-if' world of the redeemed creation. Through the Eucharistic practice, diverse creatures intentionally gather together and relate through interdependence, rather than desire for independent gain and consumption. The baker engages the limits of wheat, water, salt, and yeast to create creaturely abundance in bread. It is through this sort of relational interdependence that these creatures are able to move together toward creaturely perfection. However, the ritual does not end when the bread emerges from the oven and wine is poured from the cask. Human creatures come together in communion, gathering the diversity of creation and offering it to God in remembrance of God's redeeming work and the expectation of its full realization. This ritualization empowers practitioners to engage in kenotic service beyond the ritual, and it is this service that dangerously cracks the foundation of the consumptive social contract. The practice of baking and sharing bread invites the same careful attention in our relating to other creatures. In a world characterized by global climate change, the Eucharist asks us to live as we truly are: Creatures whose flourishing is only possible through the mutual engagement with one another and God. Intentionally gathering as a community to acknowledge our dependence on God is paramount for shunning the practices (and accompanying dispositions) that dangerously aver human independence from ecological realities. Innovative advances in theological education, such as Princeton Theological Seminary's agriculturally based theology and ecology curriculum, serve as examples of how Christian ritualization can thoughtfully and practically

5 Jennings states a social contract refers to "norms of common consent that provide social cohesion," and the consumptive social contract has informed ethics, governance, and politics during period of change that have led to market capitalism, liberalism, and representative democracy but relied on extractive use of finite ecological resources. 
engage our ecological crisis. ${ }^{6}$ Our practices and modes of being that valorize the autonomous individual are the very practices that undermine the systems that make our mutual flourishing possible. The Eucharist invites us to shun our mindless consumption and enter the rich communion of creation. Cooking shared meals together, engaging in alternative economic models such as community supported agriculture programs, and attending to the particularities of a place take the practice and truth of communion into everyday life. The subjunctive 'as-if' world continues at the dinner table where all creatures are welcome.

Funding: This research received no funding.

Conflicts of Interest: The author declares no conflicts of interest.

\section{References}

Groppe, Elizabeth T. 2005. Creation Ex Nihilo and Ex Amore: Ontological Freedom in the Theologies of John Zizioulas and Catherine Mowry LaCugna. Modern Theology 21: 463-96. [CrossRef]

Irwin, Kevin W. 2005. Models of the Eucharist. New York: Paulist Press.

Jennings, Bruce. 2016. Ecological Governance: Toward a New Social Contract with the Earth. Morgantown: West Virginia University Press.

McFarland, Ian A. 2014. From Nothing: A Theology of Creation. Louisville: Westminster John Knox Press.

Morrill, Bruce T. 2000. Anamnesis as Dangerous Memory: Political and Liturgical Theology in Dialogue. Collegeville: Liturgical Press.

Schmemann, Alexander. 1973. For the Life of the World. Crestwood: St. Vladimir's Seminary Press.

Seligman, Adam B., Robert P. Weller, Michael J. Puett, and Bennett Simon. 2008. Ritual and Its Consequences: An Essay on the Limits of Sincerity. New York: Oxford University Press.

Zizioulas, John D. 2002. Being as Communion: Studies n Personhood and the Church. Crestwood: St. Vladimir's Seminary Press.

Zizioulas, John D. 2011. Proprietors or Priests of Creation? In The Eucharistic Communion and the World. Edited by Luke Ben Tallon. New York: T\&T Clark, pp. 133-41.

(C) 2019 by the author. Licensee MDPI, Basel, Switzerland. This article is an open access article distributed under the terms and conditions of the Creative Commons Attribution (CC BY) license (http://creativecommons.org/licenses/by/4.0/).

6 See https://www.ptsem.edu/discover/farminary/overview for more information about Princeton Theological Seminary's "Farminary" and Certificate in Theology, Ecology, and Faith Formation. 